E N T R E V I S T A

\title{
ENTREVISTA COM ROBERT FRANK
}

\section{Interview with Robert Frank}

CONCEDIDA A AlEXANDRE MORELI

Paris, 10 de junho de 2016

http://dx.doi.org/10.1590/\$2178-14942017000100015

Alexandre Moreli é professor da Escola de Ciências Sociais da Fundação Getulio Vargas (CPDOC/FGV).

0 entrevistador agradece a Cristiano Fagundes, Charlotte Riom, Raissa Pose Pereira e lago Gama Drumond pelo trabalho de transcrição, revisão e apoio na redação das notas explicativas presentes no texto. 
ascido em 28 de janeiro de 1944 na Escócia, filho de mãe escocesa e pai polonês, Robert Frank fez seus estudos na França e na Inglaterra, tornando-se um historiador especializado em Relações Internacionais e herdeiro de uma das mais antigas tradições nesse domínio. É professor de História desde 1968, obteve o título de doutor em 1978 e a habilitação para conduzir pesquisas em 1990. Lecionou na Université Paris X-Nanterre de 1977 a 1991 e foi diretor do Instituto de História do Tempo Presente de 1991 a 1994. Nesse último ano começou a lecionar História das Relações Internacionais na Université Paris I - Panthéon-Sorbonne, tornou-se diretor do Mestrado em Relações Internacionais e assumiu também a direção do Institut Pierre Renouvin e do laboratório de pesquisas Identités, Relations Internationales e Civilisations de l'Europe do Centre National de la Recherche Scientifique. De 2010 a 2015 foi Secretário Geral do Comitê Internacional de Ciências Históricas. É autor de diversas obras, entre elas Le prix du réarmement français (1935-1939), Turbulente Europe et nouveaux mondes (1914-1941), La loi des géants (1941-1964) e La hantise du dédin, na qual o sintetiza seus trabalhos anteriores sobre as relações de segurança, poder e identidade no contexto do declínio da França entre 1914 e 2014. Atualmente, é professor emérito da Université Paris I - Panthéon-Sorbonne e membro da Comissão de Arquivos Diplomáticos do Ministério dos Assuntos Estrangeiros da França.

\section{Professor, preparei esta entrevista dividindo-a em quatro partes: o início da sua} carreira, o campo da História das Relações Internacionais, o lançamento da revista Monde(s) e, para finalizar, uma breve reflexão sobre o futuro da disciplina. Li algumas entrevistas nas quais o senhor afirma que, sem a terrível Segunda Guerra, até mesmo sem Hitler e sem a guerra-mundo que ele provocou, colocando pessoas e realidades muito diferentes em contato, não teria havido a menor chance de seus pais se conhecerem. Poderia nos contar a origem de sua família?

Sim, tenho uma relação paradoxal com a Segunda Guerra Mundial, e bastante existencial, pois sem a guerra e, logo, sem Hitler, eu jamais poderia ter nascido [risos], porque meu pai, nascido em Varsóvia em 1918, e minha mãe, nascida na Grã Bretanha em 1925, jamais teriam conseguido se encontrar. Meu pai é judeu polonês, de uma família relativamente abastada à 
época, de uma Polônia na qual uma parte da comunidade judaica se laicizava - minha família não viveu nos bairros judaicos de Varsóvia, eles inclusive eram um tanto aburguesados. Tanto isso é verdade que nos anos 20, com o renascimento da Polônia e os contatos com a França, uma boa parte da burguesia varsoviana colocava os filhos no Liceu Francês de Varsóvia, e foi lá que meu pai estudou. Em 1935, a família decidiu mandar aquele adolescente para Paris morar com os tios que já estavam lá, e foi então que meu pai ingressou no Licée Lakanal. Quando a guerra começou, em 1939, ele já estava na Faculdade de Direito em Paris. Após a derrota polonesa, o governo polonês veio para Paris e ele então participou da campanha de 1940 do exército polonês na França. E o exército polonês na França, como todos os outros exércitos na França... foi derrotado.

Após a derrota francesa meu pai permaneceu na França, mas mudou-se para Grenoble e continuou seus estudos de Direito até 1942, quando decidiu se juntar às forças polonesas na Grã-Bretanha. Ele passou pelos Pireneus, mas somente após a segunda ou terceira tentativa chegou ao campo [de concentração] de Miranda [na Espanha]. Lá Ihe disseram: "Fique tranquilo, você será contatado por serviços dentro do campo, que o ajudarão a sair daqui". Foi o que aconteceu, via Gibraltar. Nessa época o exército polonês estava na Grã-Bretanha, mais precisamente na Escócia. Dá para deduzir o que aconteceu... Foi aí que ele encontrou minha mãe, escocesa. Eles se casaram em 1943 e eu nasci em 1944. E se eu chamo esse caso de "paradoxo", é porque foi graças a Hitler que eu nasci, mas por outro lado foi também por ele que toda a minha família judia polonesa foi exterminada.

\section{O senhor fala bastante da guerra, mas não fala muito sobre o pós-guerra. Com referências familiares separadas pela cortina de ferro, até que ponto o senhor levou em conta os discursos e ações políticas que propagavam ou defendiam os dois lados da Guerra Fria?}

É uma pergunta interessante porque, claro, naquela altura, logo após a guerra, eu ainda era uma criança, adolescente a partir dos anos 50.0 mundo era visto muito através dos amigos, do ambiente em que se vivia, dos pais, e meu pai foi muito importante naquela minha primeira cultura política. Ele era de esquerda, era bem à esquerda, mas uma coisa ele não queria: o comunismo. Ele não queria voltar para a Polônia, que se havia tornado comunista. Ele sabia que, se voltasse, não poderia mais sair. E então ele me contava que estava entrando no Partido Socialista, que tinha um bocado de amigos comunistas que diziam: "Mas você tem as mesmas ideias que nós, por que você não nos acompanha?", e ele respondia: "Não, não posso... Sim, me sinto um pouco marxista, tenho mais ou menos as mesmas ideias que vocês, 
mas a forma como o marxismo foi aplicado nos países comunistas sob tutela soviética, não é isso que eu quero".

Foi mais ou menos nesse ambiente que eu vivi, e assim, quando começou a détentena Polônia no fim dos anos 50, quando Gomulka chegou ao poder, nós recebíamos em casa alguns intelectuais poloneses que vinham à França e podiam retornar em seguida porque havia a détente. Então, nessa Guerra Fria, eu tive... como dizer... uma cultura um tanto mitigada, na qual o império soviético era o mal, mas em que o capitalismo tampouco era bom, uma cultura que, no limite, entendia que era preferível reformar o capitalismo por dentro do que importar o modelo soviético. Foi mais ou menos nessa cultura política que eu vivi um pouco da minha infância e a minha adolescência.

\section{O senhor é herdeiro de uma importante tradição da História das Relações Internacionais na Europa continental. Seu interesse pelo estudo da disciplina histórica, de imediato, e posteriormente por essa subárea, manifestou-se quando, em sua trajetória? Sua entrada no campo da História está ligada de alguma forma ao seu percurso pessoal, familiar?}

Eu diria que de início foi uma entrada, digamos, intelectual, em meio a esse banho de cultura que acabo de descrever. Quando comecei os estudos de História fui influenciado pela École des Annales, que na época dava muito mais importância à História Econômica, 0 que muitas vezes se esquece. Claro, mais tarde viria o que seria chamado de História Intelectual, História das Mentalidades, mas antes era a História Econômica com, digamos, um certo verniz - e eu tomo cuidado ao dizer isso - um certo verniz marxista, intelectualmente marxista, mas de forma alguma militante e ainda menos comunista. Mas a ideia de guerra de classes... sim, ela existia [risos], o que não levava necessariamente à dedução de que havia um sonho socialista absoluto. Mas enfim, esse método me interessava muito na História, ver a importância da História Econômica do ponto de vista explicativo. Foi por essa razão que em 1967, quando escolhi um tema para a dissertação do Diplôme d'Études Supérieures, 0 que chamamos de Master [Mestrado] hoje em dia, eu queria fazer História Econômica. Aliás, História Econômica e Social. Fui então econtrar o Pierre Villa, professor de História Econômica da Sorbonne, e disse: "Eu estou hesitando... Como eu conheço a língua inglesa, gostaria de ir para a Grã-Bretanha estudar História Britânica, ou mesmo História Social, talvez alguma coisa sobre a classe operária, ou enfim, História Econômica". Villa, que era realmente marxista e que havia feito uma tese de História Econômica sobre a Catalunha bastante extraordinária, disse: "Sobre História Social Britânica já há muita coisa escrita... Não, não, vá ver meu colega Eric 
Hobsbawn" - que não era conhecido à época - "e ele o ajudará com um tema. Por que não um verdadeiro tema de História Econômica, que é algo formador? É mais difícil que História Social, mas é formador".

Como eu tinha uma bolsa, fui ver o Hobsbawm. E foi ele quem escolheu o meu tema. Ele estava totalmente de acordo com as minhas pretensões, disse que era preciso mesmo que fosse um assunto de História Econômica e me propôs fazer algo sobre a indústria armamentista britânica entre o fim do século XIX e o início do XX. 0 interessante de tudo isso foi a ideia de analisar e tentar entender os perfis, a influência dos industriais sobre o Estado, tentar descobrir se eles tiveram um papel importante tanto na corrida armamentista como na deflagração da guerra - aí estaria presente uma dimensão política, mas analisada através da História Econômica. Esse trabalho foi imensamente formador, e é aí que vemos que a História serve para alguma coisa [risos]... Eu pude perceber que, no plano econômico, as encomendas de armamentos pelos Estados representavam entre 3 e $5 \%$ de toda a produção de aço britânica. Claro, isso não era insignificante, mas também não era grande coisa. Não era isso que explicava a radicalização e os extremismos, era difícil validar a explicação leninista das causas da Primeira Guerra Mundial. Em contrapartida, no plano qualitativo, no plano das tecnologias, claro, a indústria armamentista conseguiu alavancar a indústria siderúrgica. Eu percebi que a História era muito mais complicada do que algumas explicações marxistas um pouco simplistas tentavam avançar. 0 extraordinário foi que Hobsbawm, de um lado, e Villa, de outro, ficaram encantados! [risos] 0 que interessava a eles era a pesquisa histórica e que, no fim das contas, se encontrássemos alguns resultados que contrariavam algumas hipóteses iniciais, isso era ciência histórica, e isso era formidável! Estávamos intelectualmente no mesmo plano, e digamos que isso também me fez evoluir, sob todos os pontos de vista.

Em seguida passei no concurso, me casei, tive um filho e fui à Tunísia em nome da [Política de] Cooperação [francesa]. Voltando, em 1971, fui encontrar o sucessor de Villa, Jean Bouvier, a quem disse que queria continuar na História Econômica e que estava procurando um tema de pesquisa. Ele disse que tinha um tema para mim, que era o financiamento do rearmamento francês nos anos 1930. Tratava-se, então, de uma história financeira. E esse momento de trabaIho com história financeira, na minha opinião, no plano intelectual, foi muito, muito importante, porque através dos agentes financeiros pode-se ver tudo. Trata-se de um posto de observação. Quando você se depara com uma questão relacionada com o rearmamento, por exemplo, tem de investigar as questões orçamentárias, a indústria, as encomendas etc. Ao mesmo tempo, é preciso investigar a economia, que está por trás das finanças, e, como estamos lidando com finanças públicas, é preciso investigar o Estado, é preciso investigar os debates na Câmara dos Deputados, os debates no Senado... Em suma, é preciso investigar todos os aspectos políticos. Os agentes 
financeiros são um posto de observação fantástico entre o econômico e o político. Além disso, como se tratava de rearmamento, era possivel perceber as dinâmicas entre a realidade francesa e a realidade internacional. Sem surpresa, é possível perceber como essa história financeira do rearmamento foi me abrir as portas das relações internacionais...

Enfim, quando eu estava fazendo o doutorado, Jean Bouvier me fez ingressar no Comité d'Histoire de la Deuxième Guerre Mondiale, na sua seção econômica. Claro, minha pesquisa era um estudo sobre o período imediatamente anterior à guerra, o que me permitia facilmente pensar sobre economia e finanças durante o conflito. Mas ao entrar nesse Comitê - lembrando que estávamos nos anos 1970 -, evidentemente eu me lembrei de toda a minha história familiar e disse: "Mas é isso, claro! Terminada a minha tese, esse é o período que me interessa".

\section{Como o senhor chegou ao grupo de Pierre Renouvin na Sorbonne?}

Quando eu estava no Comitê, havia alguém muito próximo do Bouvier, que era o René Girault [sucessor de Pierre Renouvin e de Jean-Baptiste Duroselle na Sorbonne]. Girault também vinha da História Econômica, mas já se encontrava na História das Relações Internacionais. Eu, que estava um pouco mais para a História Econômica, mas já interessado nas relações franco-britânicas, acredito ter de alguma forma chamado a atenção do Girault. Quando eu defendi a minha tese, claro, ele estava na banca. Eu lecionava no ensino médio, no Liceu de Boulogne, e buscava uma vaga de professor assistente, como se dizia à época, algo muito difícil, pois existiam pouquíssimas oportunidades na universidade. Um belo dia, Bouvier me disse: "Bom, ainda não existe vaga, mas se ela surgir... Aparentemente René Girault está pensando em você, mas será preciso uma certa conversão, ou seja, mesmo se você mantiver o interesse pela História Econômica, você migraria também para a História da Relações Internacionais". E eu, que praticamente já estava fazendo isso, disse: "Sem problema". E foi assim que aconteceu.

\section{Percebe-se um certo diálogo com o marxismo e a presença de reflexões primando pela História Econômica no início da sua carreira, num percurso que agregou cada vez mais novas perspectivas de análise. No seu modo de ver, a interdisciplinaridade, ou mesmo o esfacelamento das grandes divisões das Ciências Humanas criadas no século XIX, aconteceu como e em que ritmo? Pode-se dizer que ao longo do século $\mathrm{XX}$ voltamos a construir um historiador de perfil erudito, um humanista típico do pré-positivismo?}

Você está fazendo referência à passagem da História como disciplina fechada sobre ela mesma para uma disciplina em diálogo com as Humanidades, mais aberta? 
Exato. Por exemplo, nota-se que a História Política da tradição de Albert Sorel [historiador diplomático francês] transformou-se ao dar um passo em direção à História Econômica entre o final do século XIX e a primeira metade do século XX. Nas décadas seguintes, tem-se a impressão de que esse tipo de mudança passou a acontecer muito mais rapidamente, de que o intercâmbio entre as Ciências Humanas se acelerou. Nota-se, por exemplo, que os historiadores passaram a tomar emprestadas as ferramentas metodológicas dos sociólogos, dos antropólogos, para conduzir suas pesquisas. Tem sido essa a sua impressão? Pode-se falar em uma aceleração desse fenômeno a partir de um certo momento?

Acredito que é isso mesmo. E aqui posso falar sobre a França, que é o caso que conheço melhor. Acredito, na verdade, que o entre guerras foi sem dúvida um momento extremamente importante nesse sentido. Existem, então, dois momentos para a disciplina histórica: um que eu chamaria de "intelectual" e outro, muito mais ligado à rivalidade entre os historiadores, entre grupos, um momento "psicológico", de atritos, de disputas. Eu me explico. Obviamente temos, em 1929 e início dos anos 30, a fundação da revista Annales. Temos Marc Bloch, temos Lucien Febvre, que, claro, proporcionaram diversos tipos de mudanças. Minha hipótese é a seguinte: temos Pierre Renouvin, que estaria no início de sua carreira fazendo uma história mais clássica, uma história política e, talvez, um pouco social. Antes da Primeira Guerra ele havia começado uma tese sobre as assembleias provinciais em 1787 - o que não tinha nada a ver com a História das Relações Internacionais. Já a experiência da Primeira Guerra Mundial, claro, fez com que ele percebesse a relevância das relações internacionais. Ele terminou a tese, mas já nos anos 20 ele estava nessa nova história, das relações internacionais. Seu percurso de então é conhecido: ele e outros foram encarregados pelo governo [francês] de rever as causas da Primeira Guerra Mundial com o desafio, digamos, político, de mostrar que a Alemanha havia sido responsável pela guerra e que o artigo 231 do Tratado de Versalhes - contestado pela Alemanha - estava bem fundamentado. Renouvin estava portanto nessa equipe, que ele iria rapidamente dirigir, quando aconteceram duas coisas. Em um primeiro momento, ele decidiu gastar o tempo que achava conveniente e não responder rapidamente à demanda política. Segundo, ele apresentou conclusões muito, muito relativizadas, que não responsabilizavam totalmente a Alemanha, talvez até reconhecessem uma responsabilidade austro-húngara e alemã maior que as outras, mas, de toda a forma, eram conclusões cheias de nuances. Aliás, todas essas conclusões apareceram somente em 1932, depois do fim da questão das reparações [risos], prova de que ele decidiu gastar o tempo que achava conveniente. De toda forma, o que é importante do ponto de vista intelectual e epistemológico é que, ao fazer esse 
levantamento, a equipe se deu conta de que os arquivos diplomáticos são fundamentais para compreender as causas Primeira Guerra Mundial, mas não bastam. Assim, desde os anos 30 Renouvin - inspirado pelos Annales, apesar de não assumir isso [risos] - compreendeu que era preciso levar em conta uma outra história.

Por outro lado, também no início dos anos 1930, Lucien Febvre escreveu um artigo muito crítico em relação à História Diplomática, como se ainda não houvesse ocorrido uma mudança, como se ele não tivesse lido os primeiros artigos de Renouvin. Então temos, de um lado, uma História Diplomática que vai mudar de status e que vai se tornar, graças a Renouvin, uma História das Relações Internacionais, inspirada nos Annales, mas sem assumi-lo, e, de outro, os Annales, que vão fazer de conta que a História Diplomática não havia mudado, e vão permitir a seus integrantes - primeiro a Lucien Febvre e, depois da Segunda Guerra, Fernand Braudel - difamar severamente uma história que eles chamavam de tradicional, quando ela já havia mudado!

Após a Segunda Guerra Mundial, nota-se de forma muito marcada uma terrível rivalidade entre esses grupos, entre Renouvin na Sorbonne e Braudel na École des Hautes Études en Sciences Sociales - EHESS, que acabava de ser criada. Tratava-se de algo muito mais pessoal, na verdade, de saber quem era o "dono" da História, de determinar o destino das vagas que se abriam. Entretanto, no plano intelectual, a diferença é menor do que se crê. Qual é a diferença? É que, enfim, Renouvin continuou a se interessar também pela História Política e a História Militar, mesmo querendo renová-la com uma História Social e Cultural, enquanto Braudel tendeu, como fizera Febvre 20 anos antes, a ter uma visão, digamos, caricatural da história que era feita por Renouvin.

Tudo isto é para dizer que, para além das disputas, no final das contas o conhecimento circula [risos]. Para além das disputas, existe no plano intelectual uma circulação que toca todos os espíritos, mesmo que no plano da pequena política tenham continuado a existir rivalidades em instituições como a Sorbonne e a EHESS, utilizando os debates intelectuais somente como pretexto.

Para continuarmos no plano epistemológico, é interessante pensar que Sorel estudou o conflito franco-prussiano somente alguns anos depois da guerra, lembrar que ele publicou a História diplomática da Guerra Franco-Alemã (1875) somente alguns anos após o fim do conflito. Mais adiante, Renouvin trabalhou a Grande Guerra pouco depois de ela ter terminado. Duroselle, por sua vez, logo depois da Segunda Guerra realizou diversos trabalhos junto com cientistas políticos americanos sobre o que seria a história recente. Tem-se a impressão de 
que naquela época, talvez mais do que hoje, havia um contato dos historiadores com os cientistas políticos e com a Ciência Política (ainda que na época ela não tivesse esse nome). Como entender a evolução da História para além desse diálogo já mencionado com os Annales, considerando a tradição da Ciência Política?

Eu penso que esses historiadores mencionados, antes de se relacionarem com a Ciência Política, foram historiadores que se interessaram pela atualidade. Nesse sentido, ao se interessarem pela atualidade, eles faziam de forma vanguardista - pois eram ideias muito avançadas para o seu tempo - o que hoje chamamos de História do Tempo Presente... Sorel, de fato, iniciou seus trabalhos muito pouco tempo depois da guerra de 1870. Renouvin, muito pouco tempo depois da de 1914-18, lembrando também que esses homens haviam sido traumatizados por essas guerras... Esse foi de fato um paradoxo, pois logo depois da Segunda Guerra Mundial, e mesmo até os anos 1960, quando era o caso de se fazer História do Tempo Presente (lembrando que o Instituto de História do Tempo Presente foi criado por François Bédarida em 1979), houve reticências e resistências. Dizia-se: "Como podemos fazer a história de períodos tão recentes?", enquanto os predecessores, na verdade, já o faziam! Nos anos 1960, em nome da tradição [risos], alguns - e digo alguns - condenavam a História do Tempo Presente enquanto aqueles tidos como "tradicionais" já a haviam feito antes! Havia aí um imenso paradoxo. Essa batalha entretanto terminou, felizmente. Estamos falando, então, de pessoas que se interessam pela atualidade e, porque se interessam pela atualidade, dialogam com o que podemos chamar de Ciência Política.

Outro aspecto a ser destacado é o fato de que o trauma de 1914-18 é muito mais importante do que o trauma de 1870-71. Sim, ele é mais importante, mas por quê? Porque houve muitos mortos, foi uma carnificina. 0 próprio Pierre Renouvin foi mutilado, na própria carne. Não se trata, porém, de subestimar o trauma de 1871, que certamente resultou em muito menos mortos, mas foi uma derrota. Tanto é assim que a ideia das pesquisas em Ciência Política de Boutmy foi poder pensar sobre a formação das novas elites. As questões a serem então respondidas eram: teriam as elites francesas fracassado? Teriam as elites francesas demonstrado algum tipo de inferioridade diante das elites prussianas e alemãs, que venceram a guerra? A Sciences Po [Ecole Libre des Sciences Politiques] foi então criada para renovar essas elites, modificar o ensino, a formação etc., e Sorel, como historiador, estava plenamente envolvido nessa transformação. Daí sua entrada na Sciences Po e, portanto, sua ligação substancial com os cientistas políticos. Já para Renouvin, da geração seguinte, o que se passou foi talvez mais complexo. Não sei a data exata, mas acredito que logo depois da Segunda Guerra 
Renouvin entrou rapidamente em contato com a Sciences Po, onde iria lecionar em razão da relevância da História das Relações Internacionais na formação dos alunos. Duroselle faria algo parecido ao fundar o CERI, Centre de Recherches Internationales, organizando até mesmo um seminário com Raymond Aron. Dessa forma, houve, sim, uma circulação entre historiadores, cientistas políticos, filósofos e sociólogos.

Nota-se, em suma, a importância das guerras, do contexto pós-guerra, criando uma ligação mais estreita desses historiadores com os cientistas políticos, fazendo com que a História Política subsistisse neles muito mais do que o que aconteceu do lado dos Annales, o que talvez explique a já mencionada diferença, ainda que todos esses que citei, com Renouvin à frente, tenham se inspirado nos Annales. A dimensão política era importante demais.

\section{É interessante como ainda não mencionamos a expressão "forças profundas". Penso no pós-guerra e no período de sua vida que comentamos agora, o que nos faz lembrar da obra Introduction à l'Histoire des Relations Internationales, de Pierre Renouvin e Jean-Baptiste Duroselle, publicada em 1964 (Paris, A. Colin), um marco na tradição da qual o senhor faz parte. Do seu ponto de vista, qual foi o lugar dessa obra dentro da História? Teria ela constituído o ápice de um ciclo de revisão da velha História Política ou apenas seu início?}

Esse ciclo começa certamente antes! Na verdade, há um artigo de Renouvin do início dos anos 30 em que ele menciona pela primeira vez as "forças subjacentes". Ainda não usava a fórmula das "forças profundas", mas já mencionava as tais "forças subjacentes". "Força profunda" aparece, de fato, em 1954, no que eu chamo de "pequena introdução". Em 1953, Pierre Renouvin foi encarregado pela Editora Hachette de lançar uma coleção sobre a História das Relações Internacionais da Idade Moderna até nossos dias. Renouvin iria escrever somente os últimos volumes, sobre o século XIX e a primeira metade do XX, até 1945. Os volumes precedentes seriam escritos por outros, mas, claro, no primeiro volume, Renouvin fez uma introdução geral à coleção toda. Em 20 páginas, essa "pequena introdução" anunciava a grande introdução de 1964, que ele escreveu com Duroselle. E aí, passamos às "forças profundas".

Também aí, Renouvin mais uma vez se inspirou na École des Annales, que ele não cita, dizendo que havia "várias escolas" e que seria preciso levar em conta "todas essas escolas". Seria preciso, ele diz, ter em conta a escola clássica da História Diplomática, mas também a escola "estrutural", e aí é preciso entender que, de fato, tratava-se justamente dos Annales. É um longo percurso que está ligado de certa forma aos anos 30 . Devido às rivalidades, ele cita Braudel só depois, num artigo, na verdade uma ou duas vezes, quase sem querer... [risos]. 
Percebe como os grandes historiadores são apenas homens [risos], e que as pequenas e mesquinhas rivalidades entre eles infelizmente também existem?

Sabemos bem o que seguiu nos anos 70 e 80 , mas eu gostaria de abordar uma categorização muito utilizada hoje em dia, a da suposta "virada global". Gostaria de lançar o debate perguntando se é possível definir as mutações no campo histórico como consequência de uma "virada global" dos processos sociais nos últimos 30 ou 40 anos, como, por exemplo, através de uma suposta sincronização dos processos sociais causando repercussões na maneira como se pensam as Ciências Humanas.

Sobre esse assunto há muito a dizer, eu acredito. Acredito que talvez tenhamos tido, logo antes da "virada global", aquilo que poderíamos chamar de "virada cultural", ou seja, o real nascimento de uma História Cultural, que é independente da História Política e é feita por fora da História das Relações Internacionais. Como ocorre com frequência, essa História Cultural, de diferentes formas, dá fôlego à École des Annales. Valem alguns comentários, por exemplo, sobre a própria aparição da palavra "cultura", da palavra "cultural". Ela é tomada da Antropologia, claro, porque cultura e cultural vão mais no sentido antropológico, não se tratando somente da grande cultura, das belas artes, do Parthenon, mas também da cultura do cotidiano... Do lado da História das Relações Internacionais, as ferramentas e conceitos eram os mesmos que encontrávamos desde o início: as mentalidades, a psicologia social... Havia ainda a economia, também importantíssima na École des Annales, mas os termos cultura e cultural levaram um certo tempo para substituir essas palavras. Entretanto, a partir dos anos 80 essa mudança aconteceu, e a História das Relações Internacionais introduziu essa terminologia também na sua disciplina, incluindo a "história das representações". Não se falaria mais apenas em termos de "mentalidades", mas de "representação". Eu diria que, sobretudo a partir dos anos 1990, a História em geral e a História das Relações Internacionais em particular começam a se interessar ainda mais por essa história das percepções, por essa história das representações.

René Girault, por exemplo, no final dos anos 1990, lançou uma rede europeia para estudar a percepção de potência enquanto poder nas relações internacionais, analisando os anos de 1938, 1958 e os anos 1960. 0 objetivo era não somente pensar sobre as grandes potências ou sobre as potências médias em um plano objetivo, mas entender como elas criavam representações delas mesmas e das demais, e como as representações das potências criam poder ou o fazem desaparecer. Em outros termos, como a representação da realidade 
transforma a realidade. Aí penso que se trata de uma virada essencial. Chamei tudo isso de virada cultural. Ao mesmo tempo, ou quase, um pouco mais tarde, ocorreu essa virada global e transnacional. Ou seja, a ideia segundo a qual é preciso sair dos quadros nacionais ... [pausa] mas isso é dito há muito tempo! Marc Bloch já dizia isso em 1928 no Congresso de Oslo! Até mesmo Sorel dizia que, quando fazemos História Diplomática, é preciso ver não apenas os arquivos nacionais... até mesmo quando se pensa especificamente sobre a História da Política Externa da França! Bem... até aí, todos já estavam de acordo, mas, por causa de problemas materiais, nem todo mundo pode generalizar isso. Assim, a História global não demanda apenas sair das fronteiras nacionais, mas perceber as circulações internacionais que fazem 0 mundo. Isso é o que há de mais novo... o que, para mim, mais revoluciona.

Paralelamente à virada cultural, à virada global, existe a reivindicação por uma chamada virada transnacional, sobretudo através da influência da Ciência Política americana. Esse movimento parece ter colocado a escola de Pierre Renouvin em uma situação difícil, parece tê-la deixado um pouco cambaleante. Porque no fundo, essa chamada História Transnacional, ou o termo transnacional dentro desse movimento, pretende designar todas as relações através das fronteiras que não passavam pelos Estados, ou seja, todas as relações que não eram interestatais. Isso seria, então, chamado de transnacional. Ora, há então um problema! Vemos aqui como se fazem algumas ditas revoluções... Algumas se fazem, na verdade, sem levar em conta o que foi dito antes! Ora, se antes houve de fato uma revolução "renouviana" [risos], prolongada por Duroselle, foi precisamente através dos ditos em seu artigo dos anos 1930 ou, ainda melhor, nos ditos de sua "pequena introdução" de 1954 e na "grande introdução" de 1964. Ou seja, se nós [da escola francesa] preferimos a expressão "História das Relações Internacionais" à expressão "História Diplomática", é porque, para nós, e eu cito [Renouvin], "a história das relações internacionais não é somente a história das relações interestatais, mas é também a história das relações entre os povos". Sabemos que a palavra "povos" está em desuso hoje, mas ela equivale a "sociedades".

Finalmente, para Renouvin, então, a História das Relações Internacionais seria tanto a história das relações interestatais como o que hoje é chamado de relações transnacionais, ainda que a palavra não existisse à época. Tudo isso criou uma confusão, sobretudo porque nós propomos, ainda, outra coisa: reservar o termo transnacional às relações - pouco importando se são interestatais ou ainda menos se são intersocietais - que, de uma forma ou de outra, esquecem o nacional, ou ultrapassam o nacional ou transcendem o nacional, observando, porém, que nem todas as relações entre sociedades são transnacionais - por exemplo, quando um produto deixa um espaço nacional e vai até outro espaço nacional sem ser percebido como perdendo a sua origem, como sendo de uma outra nação, não há transformação! Em 
contrapartida, se esse produto tem um valor simbólico que porta culturalmente aspectos de apropriação ou reapropriação, ou seja, de transferência e, assim, de esquecimento ou transcendência do nacional, então aí podemos chamar de transnacional! Evidentemente, a exportação de Coca-Cola para o mundo não se resume apenas a uma venda de refrigerante [risos], mas constitui uma série de símbolos que são reapropriados. E aí, de fato, tudo muda!

É por esse motivo que na conclusão do livro Pour l'Histoire des Relations Internationales, de 2012, dizemos que a ideia de forças profundas de Renouvin ainda é válida, mas também que é preciso adaptá-la, modificá-la, e metamorfoseá-la completamente. Por quê? Porque mesmo que Renouvin tenha sido o primeiro a dizer que as relações internacionais não são apenas as relações entre Estados, mas também relações entre povos, é preciso admitir que, em seus escritos, e nos de Duroselle também, apesar de tudo, foram estudadas essencialmente as relações interestatais. Mesmo que se estudassem as forças profundas, viam-se as forças sociais, culturais, econômicas, sobretudo num plano vertical, ou seja, como em uma sociedade, em um quadro nacional, influenciavam bottom up o Estado Nacional, assim como a rigor o Estado Nacional, com sua ação, podia up down metamorfosear as forças profundas. Era, então, uma espécie movimento vertical, de baixo para cima e de cima para baixo.

É interessante, assim, como nós propomos, de outra maneira, uma fórmula de "dinâmica internacional", ou "dinâmica transnacional" - e a propósito, uma bela coincidência, pois a palavra "dínamo" quer dizer "potência" em grego, "força" [risos] -, que considera movimentos horizontais que atravessam fronteiras. Quer dizer, com as forças profundas sendo vistas como formas de circulação através das fronteiras, como essas forças profundas nacionais atravessam fronteiras e são reapropriadas por outras e chegam a uma coalescência internacional ou transnacional que, finalmente, pode influenciar todos os Estados ao mesmo tempo, ou de forma sucessiva, e ao mesmo tempo transformar as relações internacionais.

Mas há muita cacofonia por trás desse debate! Para ir mais longe, ainda sobre 0 transnacional, confunde-se duas coisas: confunde-se a abordagem e o objeto. A abordagem é o método. 0 sentido de transnacional é sair do quadro de análise nacional, ver as circulações etc. Mas objeto é outra coisa! Não é porque temos uma abordagem transnacional que vamos encontrar objetos transnacionais [risos]. Talvez encontremos objetos transnacionais, mas às vezes eles serão absolutamente internacionais, objetos que vão de uma nação a outra, mas que guardam o caráter nacional de origem. Não encontraremos necessariamente objetos transnacionais. Supondo que encontremos objetos transnacionais por todos lados, seria algo praticamente ideológico, porque chegaríamos, assim, a uma espécie de mundo gentil, irônico, onde os fatos nacionais são ultrapassados e onde tudo vai bem graças às circulações culturais... Mas não é assim! A história também é trágica. 
Estamos chegando a quase quatro anos da obra que o senhor organizou em 2012 (Pour I'Histoire des Relations Internationales), que, por sua vez, foi pensada em dez anos, e na qual o senhor advoga a herança de abordagens ou métodos que hoje são apresentados como inéditos. Seria já possível fazer um inventário dessa obra, do impacto ou até dos resultados que o senhor mostra em mais de $\mathbf{3 0}$ capítulos?

Penso que seria difícil. É uma obra que foi pensada ao longo de dez anos e que, logo, viveu um pouco todas essas viradas. Na verdade, o objetivo era mostrar em que sentido as aquisições antigas e recentes permaneceram importantes, mas também que as novíssimas aquisições poderiam enriquecer sem necessariamente negar as heranças. Em particular em nossa conclusão, chegamos à ideia de que, uma vez mais, é preciso tomar cuidado com as expressões que utilizamos. Na verdade, devido à chamada virada global e à virada transnacional, nos Estados Unidos e em outros lugares questiona-se se não se deve mudar o nome da disciplina e utilizar preferencialmente "História Internacional", que evoca um pouco da história transnacional, no lugar de "História das Relações Internacionais". E por que não? Quero dizer, se algum dia isso se impuser, impor-se-á. Mas se nós nos apegamos ao termo "relações"... [risos], é porque invertemos a problemática, a saber: todos os historiadores deveriam fazer história internacional. Todos. Em especial aqueles que fazem história nacional [risos]. Não podemos fazer a história de uma nação sem fazer a história internacional dessa nação. Explico: não somente a política externa, evidentemente, mas isso não é o mais importante, uma nação é feita de intercâmbios, de trocas, internacionais e transnacionais. Uma nação é uma construção histórica. Pode nascer e pode morrer. A britishness está morrendo devido ao Brexit. Quero dizer, o Reino Unido tem uma identidade britânica que está se desfazendo sob os nossos olhos. É, então, mortal. 0 que isso quer dizer é que a história da França, a história da Alemanha, a história do Brasil etc. não podem ser escritas sem essa visão internacional. Não podemos permanecer apenas nos arquivos do próprio país para explicar o país. Não podemos permanecer no interior das fronteiras desse país para explicar esse país. Toda história é, portanto, internacional. Nesse contexto, a nossa especificidade, nossa excepcionalidade são justamente as relações! Paradoxalmente, não é a palavra "internacional" que é original, porque todos deveriam praticá-la, mas as condições através das quais essas relações se organizam. Quando fazemos a história internacional da França, por exemplo, não buscamos analisar em detalhes as relações com outros países, as relações societais etc., buscamos somente aquilo que nos é interessante para explicar a França. Já na História das Relações Internacionais, justamente, estamos atrás de uma história um pouco geral dessas relações. Essa é a especificidade. 


\section{E não é pouco, sobretudo na América Latina, onde a história nacional é uma tradição muito forte.}

0 que é normal! Quer dizer, toda nação é uma construção perpétua, certo? Até mesmo as nações mais antigas, até mesmo a França, estão em perpétua construção. A nação brasileira, não quero dizer que é novíssima, ela já tem sua história, mas vai fazer 200 anos, não é isso? E não são nada 200 anos... nada... [risos]. 0 que quero dizer com isso é que é normal ver em todos os países, e particularmente naqueles que chamávamos no entre guerras de "países novos", que a história nacional ainda é importante. Mas precisamente, dentro dessa história nacional, é preciso fazer a história internacional do Brasil. E transnacional do Brasil.

Foi o que permitiu, por assim dizer, a pequena revolução trazida por Michel Espagne e Michael Werner, com a noção de transferência cultural, quando da reflexão deles sobre a história comparada. Eles queriam fazer a história comparada da França e da Alemanha, e se deram conta de que, enquanto o termo "história comparada" é muito bom, ao tomar a palavra "comparada" no seu sentido estrito, passariam a comparar um bloco e outro bloco, a França e a Alemanha. Identificariam, assim, diferenças, similaridades, mas como se fossem blocos! Justamente, o que embaralha a comparação é que não se trata de essências, que não são blocos, mas que, precisamente, existem relações culturais, fenômenos de transferência e de apropriação que fazem com que a França e Alemanha não sejam essências, mas se inspirem mutuamente.

\section{Mas então, a tradição de Renouvin já respondia a essa atenção às perspectivas, porque essas "relações" estavam presentes desde o início das transformações epistemológicas que ele propôs para a disciplina.}

Verdade. Isso tudo era dito, mas na prática, nos escritos que se sucederam, as relações interestatais venceram. É verdade, também, que nessa época se percebia que as sociedades exerciam um papel. 0 que Renouvin chamava de forças profundas exercia um papel. Ao mesmo tempo, apesar de já haver circulações internacionais entre essas forças profundas, elas eram talvez menos ... óbvias, menos evidentes, menos espetaculares que desde os anos 70 . A terceira globalização que hoje conhecemos tem uma particularidade em comparação com a globalização imperial do fim do século XIX, início do XX, ou com a segunda globalização dos anos 20, da multiplicação de todas essas circulações. 0 que faz com que tenhamos um fenômeno um tanto novo: a ascensão ao poder não das sociedades, mas da sociedade civil. É uma outra coisa. Ou seja, aquela parte da sociedade que se engaja em redes, associações, 
organizações não governamentais, e que pesam na vida internacional. Claro, antes havia a Cruz Vermelha, mas era uma só ONG. Havia redes internacionais, mas digamos que a partir dos anos 1970 a sociedade civil tornou-se muito mais importante que antes. Trata-se da questão dos limites e não da inexistência da potência estatal.

Desse ponto de vista, Renouvin, tendo ideais novas que podemos finalmente aplicar completamente hoje em dia, não levou até o fim suas novas perspectivas. Porque era uma época em que as forças profundas estavam mais verticalizadas, como dizíamos há pouco, e, apesar de já existir, era menor a horizontalidade de circulação de forças que hoje se multiplicam em uma escala e um grau que modificam até mesmo sua própria natureza. Foi a própria História que mudou, e é preciso que os historiadores levem isso em conta. Sobretudo se estudarem uma época extremamente recente, dos anos 1970 para cá.

Há uma expressão cara ao senhor, e sobre a qual eu gostaria de um comentário seu, que é "pensar historicamente as relações internacionais". Como trabalhar essa relação entre Teoria e História das Relações Internacionais? Podemos fazê-lo?

As teorias me interessam, e me interessam porque me ajudam a pensar [risos]. Para mim, são ferramentas.... Não sou produtor de teorias, sou consumidor de teorias e eu vou às compras na teoria, pego aquilo que me interessa, escolho o que me interessa... Mas vejo que nenhuma teoria sozinha consegue produzir explicações. Por causa das inúmeras teorias, é importante que o historiador conceitualize. Para mim, o conceito está entre o fato e a teoria. Tudo isso significa que as teorias permitem que se reflita sobre a forma de agenciar os fatos, de reinterpretar os fatos. Entretanto, como nos damos conta rapidamente de que elas não conseguem dar cabo da riqueza dos fatos, é preciso parcelar as teorias e tomar emprestados os seus conceitos. Considerar cada pequena partícula, por assim dizer, das teorias. Talvez não todo o conjunto, mas certas partículas, que podemos encontrar tanto com os funcionalistas, os institucionalistas, os realistas, os idealistas, os transnacionalistas, os construtivistas. Seus conceitos, finalmente e efetivamente, nos servem para melhor reinterpretar os fatos ou para apresentar as interpretações dos fatos. Para mim, a palavra-chave é conceitualização.

René Girault, que o precedeu na Sorbonne, dizia que "todo historiador é prisioneiro do seu tempo". Temos aqui uma questão: não é paradoxal que 0 , digamos, combate dos historiadores globais, ou ao menos de alguns, contra o paradigma nacional, ocorra na mesma época em que há um aparente retorno muito acentuado da lógica nacional? 0 referendo britânico que o senhor 


\section{mencionou, não seria prova de que a história global deve existir somente ao lado da história nacional? Como se dá essa relação entre global e nacional hoje em dia e no século XXI?}

Acredito que a história nacional enquanto disciplina, enquanto abordagem, continuará sendo necessária. Continuará a ser necessária em um plano social. Não é ilógico que, nas escolas, no ensino médio, aprendamos a história do mundo, claro, mas que, nessa história do mundo, a história do país onde vivemos tenha um lugar privilegiado. Afinal de contas, é o ambiente onde se está, mas essa história nacional deve ser renovada, justamente por essas viradas epistemológicas que são a história cultural, história global, história transnacional, a saber, por uma visão internacional da história de sua nação. E acredito que isso seja absolutamente necessário... Cito bastante Romain Gary que, em seu romance Education Européenne, tinha uma fórmula maravilhosa sobre patriotismo e nacionalismo: "0 patriotismo é o amor dos seus. 0 nacionalismo é o ódio dos outros". É bem verdade que frequentemente confundimos os dois, atribuindo ao "nacionalismo" tudo aquilo que se refira à nação. Não, não, não! Tudo o que se refere a nação não é forçosamente nacionalista. Somente é nacionalista aquilo que, em uma nação, odeia os outros. Assim, podemos explicar um aspecto do nacionalismo de potência, que depende da oposição aos outros, que são tomados como concorrentes, o que não é o caso atualmente. As políticas de extrema direita já não constituem mais o nacionalismo de potência. Elas têm, ao contrário, um sentido de retração. De retração identitária, e o ódio por outros em seu próprio território, o ódio pelo estrangeiro, um pouco pelo estrangeiro fora das fronteiras, mas também e sobretudo pelo estrangeiro que está dentro das fronteiras. Razão a mais, eu diria, para ver a história nacional com ferramentas outras que as nacionalistas.

Gostaria de acrescentar somente mais uma ideia, sobretudo porque me parece um conceito extremamente interessante, sobre o qual trabalhei com outros, tendo sido René Girault o primeiro a trabalhá-lo. É um conceito que assusta, mas assusta, na minha opinião, indevidamente. Trata-se do conceito de identidade. Acredito que os historiadores em geral e os historiadores das relações internacionais em particular devem refletir sobre as identidades. 0 que é uma identidade? É um sentimento de pertencimento a um grupo.... familiar, do vilarejo, urbano e, claro, também, nacional que, no mundo de hoje, aparece como a principal identidade, mas está longe de ser a única. Há também identidades acima da nação: por que não uma identidade europeia? Ou talvez uma identidade latino-americana? Ou uma identidade norte-americana etc. A noção de identidade assusta porque muitos têm a impressão de que, se refletimos sobre as identidades, isso poderia significar que vamos enaltecer as retrações identitárias. Mas é justamente o contrário! Trata-se de ver como os grupos, os indivíduos, os 
meios frequentemente participam de várias identidades ao mesmo tempo e sobre como, ao fazê-lo, cada indivíduo ou grupo desenvolve uma alquimia específica.

Durante muito tempo, sobretudo nos meios realistas, falou-se com frequência das relações internacionais em termos de "equilíbrio de potências", balance of power... em termos de equilíbrio europeu, de equilíbrio das forças no interior da Europa... que existiu, mas que não funcionou muito bem. Na atualidade, me parece que é preciso pensar o mundo e as relações internacionais, se quisermos chegar a um equilíbrio, não em termos de equilíbrio de potências, que não é o mais importante atualmente, mas de equilíbrio entre identidades harmonizadas. Quero dizer que, no fundo, a fonte de desordem internacional, principalmente hoje em dia, nos últimos 40 anos - e não quero dizer que ela não ocorreu antes, mas é particularmente perigosa hoje em dia -, são todas essas identidades humilhadas ou não harmonizadas que, acredito, desencadeiam, às vezes localmente, tensões ou mesmo guerras que obrigam outros a intervir.

Bem, deixemos um pouco as tensões do mundo e voltemos à Europa e ao referendo britânico. E aí posso mostrar que essa reflexão sobre as identidades é essencial. Qual foi o erro fundamental e comum de David Cameron e também de Boris Johnson - que, claro, estavam em campos diferentes, porque um estava a favor e o outro contra a saída da Grã-Bretanha? Um diz: "Eu sou eurocéptico, mas permaneçamos na Europa, sobretudo porque obtivemos concessões da Europa". E o outro diz: "Essas concessões não são suficientes, então, saiamos da Europa"... Mas o ponto de partida é o mesmo. Qual vai ser o resultado do Brexit? Suponhamos que seja concluído... não sabemos, mas tem chances de ser concluído. A Europa, em princípio, vai ser enfraquecida. Vai romper? Talvez, mas não é certo. 0 risco vem de outro lugar. Porque nem Cameron nem Boris Johnson refletiram sobre a questão das identidades. Como eu disse antes, é o Reino Unido que corre o risco de se desfazer, e não a Europa. Ora, se pegamos Cameron e Johnson, é muito interessante porque lidamos com tradicionalistas que, por definição, são muito apegados ao Reino Unido. E eles sequer pensaram sobre o assunto! Como se o Reino Unido fosse uma essência, como se fosse um bem conquistado. Eles nem pensaram sobre 0 assunto e, no dia seguinte [ao voto do Brexit], descobriram que a Escócia está praticamente em revolta!

Veja, eu nasci na Escócia e, por isso, sou sensível a esse problema. A questão do Brexit nos coloca a questão "do que é ser escocês". Um escocês, com o perdão pela obviedade, é um escocês [risos]. Ele tem uma identidade escocesa. Mas não apenas! Ele tem também uma identidade britânica, que é mais recente, uma construção histórica do século XVIII mais ou menos, mas essencialmente do XIX e do XX: com a armada colonial, a colonização, e os escoceses tendo uma promoção social graças ao exército britânico. 0 que Cameron e Johnson esqueceram é que todos eles têm uma terceira identidade! Eles se sentem europeus. Eles têm 
essas três identidades! Então, de repente, os escoceses se levantaram na sexta-feira passada e, desde cedo pela manhã, como interpretaram o Brexit? "Os ingleses, estão nos forçando a sair da Europa!" E disseram mais ou menos isso: "Bom, somos escoceses. Europeus também. E sim, somos britânicos, mas cada vez menos, porque os ingleses nos forçam a escolher entre nossa identidade britânica e nossa identidade europeia". Não quero dizer que tudo isso seja assim tão simples. Há muitos escoceses, no caso de novos referendos, que irão optar pela identidade britânica e continuar a votar contra a Europa, mas há muitos escoceses, que vão mudar de opinião, que votaram contra a independência em 2014 e que votariam a favor caso houvesse um novo referendo.

Meu prognóstico não é seguro. Aqui falo sobre o hoje. Pode ser que, dentro de uns meses, tudo se pacifique, outros eventos aconteçam, o equilíbrio entre essas três identidades volte... e que os escoceses mudem de novo de opinião. 0 que quero dizer é que, se não refletimos sobre o sentimento de pertencimento na história das relações internacionais, passamos ao lado de muita coisa, tanto enquanto historiadores como enquanto atores políticos.

\section{Antes de passar à revista Monde(s) e ao futuro, gostaria de fazer uma pergunta sobre uma instituição que é muito conhecida no Brasil, que o senhor presidia no início dos anos 90, que é o Institut d'Histoire du Temps Présent. Foi peculiar ter um internacionalista à frente do Instituto. Como foi essa experiência? Que agenda o senhor propôs na época?}

Ah, foi uma experiência muito, muito bela. Infelizmente não durou muito tempo, pois fui aprovado [para a Sorbonne]. Fiquei apenas quatro anos. Quando Bédarida fundou o IHTP, em 1979, a ideia tinha vindo também do CNRS [Centre National de la Recherche Scientifique], onde havia um Comité d'Histoire de la Deuxième Guerre Mondiale. Henri Michel, seu fundador, estava se aposentando, e alguns do CNRS, como Bédarida, diziam: "Afinal de contas, por que não aproveitar e fundar um instituto que continue a trabalhar com a Segunda Guerra Mundial, que é fundamental, mas corresponde a apenas 6 anos no século XX? Por que não estudar as décadas seguintes?" Quando Bédarida lançou essa ideia, eu já estava no comitê, em sua seção de História Econômica, e havia lançado com Bouvier uma pesquisa sobre as empresas na Segunda Guerra Mundial. Nessa transição, em 1980, foi feito um colóquio explicando que as pesquisas sobre a Segunda Guerra Mundial continuariam, mas que novas pesquisas iriam começar etc. E me disseram: "Faça uma apresentação!" E aí, qual o tema? Tive então uma ideia, acho que incentivado por minhas origens. 0 que me marcava nas discussões da infância com meu pai polonês e minha mãe escocesa é que tínhamos, precisamente na França, uma 
versão afrancesada demais da Segunda Guerra, como se ela não fosse mundial. Não tínhamos necessariamente os outros pontos de vista e, sobretudo, eu ouvia em casa coisas com as quais não concordava, a saber: a gloriosa Grã-Bretanha, os americanos salvadores, os soviéticos que também fizeram uma bela guerra... e a França, que era tida como deplorável em meio a tudo isso.

No fundo, eu me dava conta de que a memória da Segunda Guerra Mundial envenenava a vida dos franceses. Então decidi dar uma palestra dizendo que haveria uma pesquisa fundamental, que faria a ligação entre a história da Segunda Guerra Mundial e a história do tempo presente. Essa conexão seria a história da Segunda Guerra Mundial na cabeça dos franceses depois de 1945. É interessante, aliás, que, nessa palestra, acredito, eu pronunciei a palavra "memória" uma única vez. A palavra "memória" ainda não estava na moda, mas era disso que eu falava, sem a palavra. A ideia vinha daí: como é que os franceses refazem a guerra em suas cabeças e como a explicam? 0 problema é que eles não conseguiam se identificar com ninguém. Dizia-se: "Os britânicos podem se identificar com a glória, eles resistiram e salvaram o mundo, os americanos também são salvadores. E por que não os soviéticos?". Na França havia de tudo: os heróis, os canalhas, os que estavam entre os dois, as vítimas, mas não havia aquela figura com a qual se identificar. Então eu disse: "É isso que precisamos lançar". Depois focamos mais, no que se tornou um projeto sobre a história das comemorações.

Mais tarde, quando Bédarida se aposentou, eles vieram falar comigo para que dirigisse o Instituto. De repente, já diretor do Instituto, eu repensei a Segunda Guerra Mundial, de que eu gostava pelas razões que já expus, mas em relação à qual era preciso pesquisar os anos mais recentes, para que o IHTP pudesse fazer por merecer seu nome [risos] e não fosse apenas o antigo Comité d'Histoire de la Deuxième Guerre Mondiale - mesmo se a questão das comemorações fosse contemporânea, ela ainda fazia referência à Segunda Guerra Mundial. Felizmente, outras pesquisas já haviam sido lançadas, sobre história urbana etc. Mas era preciso lançar algo sobre os anos 60, os sixties, com a ideia de que fazíamos uma história, digamos, não hexagonal - não havia ainda os termos "global" e "transnacional" -, uma história que saía do quadro nacional, com a seguinte reflexão: no fundo, quando levamos em conta todas as gerações do século XX, todas elas conheceram épocas traumatizantes; todas conheceram um pré-guerra - antes de 14 -, uma guerra - 14-18 -, um pós-guerra, novamente o pré-guerra, a Segunda Guerra Mundial, o pós-guerra, com a crise de 30 entre as duas... Mas a partir dos anos 70, tudo mudou bastante. Os traumas de todos aqueles jovens desempregados mostravam que, se antes, do final do século XVIII até os anos 70, se acreditava no progresso, se acreditava que as gerações futuras viveriam melhor do que as precedentes, de repente, tudo se rompera. Não se acreditava mais no progresso, houve um recuo. 
Os anos 60 foram os únicos que não foram nem anos de pré-guerra, nem anos de pós-guerra, nem período de crise. Além disso, havia arquivos se abrindo, e fomos estudá-los. Claro, na minha perspectiva pessoal, das relações internacionais, eu acrescentava ainda a questão da Guerra do Vietnã, porque tudo tomava ares de contestação nos "anos 68", como foram chamados. Era possivel pensar como eventos internacionais haviam provocado aquela coalescência de contestações contra todas as autoridades, contra os pais de família, contra os professores universitários, contra o patrão, contra o presidente da República... De Gaulle era como um pai, mas a contestação era contra ele também, era contra o homem que estava no topo da pirâmide do mundo, o presidente dos Estados Unidos, porque a Guerra do Vietnã estava mostrando o fim da inocência americana, estava mostrando que a "América" também sabia utilizar um lança-chamas.

\section{Passemos então aos "lugares de debate" para falar da revista Monde(s), que o senhor lançou com seus colegas em 2012. Como ela foi pensada, sobretudo em relação ao global?}

Nós estávamos na reflexão de que a História das Relações Internacionais deveria levar em conta a virada global e transnacional, mas guardando a especificidade da reflexão sobre as relações e preservando a dimensão da história política. Ao mesmo tempo, dizíamos: "Mas nos falta força..." , pois havíamos partido de Paris 1 e do Instituto Pierre Renouvin, tínhamos especialistas em Relações Internacionais, um centro de história da América Latina, um centro de história norte-americana, um centro de história russa, um centro de história da Europa Central, um centro de história da Ásia, mas o mundo não estava todo coberto: faltava a África. E o acaso fez com que os africanistas de Paris 1 - que estão à parte em um instituto próprio -, que faziam parte de uma revista chamada Afrique, rompessem com essa revista. Eu então fui vê-los e disse: "Vocês não gostariam de fazer uma revista onde haveria ao mesmo tempo História das Relações Internacionais e, como dizemos em inglês, area studies? Vamos trabalhar juntos para pôr em simbiose nossos métodos, nossas abordagens..." Ele responderam rapidamente que sim. Fizemos várias reuniões e discutimos até o título - daí Monde(s), tanto no singular como no plural. Monde no singular é a história global, e Mondes no plural são as diferentes regiões que fazem o mundo... Em seguida vinha o subtítulo Relations, que quisemos expressamente manter. Os especialistas das "áreas" regionais até questionaram: "Por que a palavra relações? Seria como utilizar a palavra militar ou político. Parece o tipo de história feito no passado!". Mas nós fizemos questão de manter a palavra, justamente porque ela contém a ideia de circulações, e não somente de relações entre os Estados. Assim, temos três palavras: Histoire, Espaces, Relations. 
0 que é apaixonante no Comitê Científico e no Comitê de Redação são as discussões, que são extremamente interessantes. Por quê? De um lado, quando um especialista em relações internacionais vai falar, alguém diz: "Cuidado, o ponto de vista dele é ocidental-cêntrico!" De outro, quando um africanista fala, alguém diz: "0 seu ponto de vista não leva muito em conta a política", ou "Você não levou em conta o ponto de vista do dominador, você faz com que o ponto de vista do dominador não exista, mas ele deixou marcas". Vemos assim como é preciso que se permaneça científico, como é importante medir o grau de autonomia do dominado em relação ao dominador, os limites da europeização e da ocidentalização. Acredito que seja necessária uma abordagem que não evacue tanto a presença dos dominadores, senão não conseguiremos explicar a história. Não se trata de dizer se a dominação foi boa ou não, claro que ela não era boa, mas não deixa de ser verdade - e isso toda a história da humanidade atesta - que toda dominação deixa marcas com as quais as pessoas vivem, das quais não conseguem se desfazer. 0 que quero dizer com isso, precisamente, é que, se relacionarmos os subaltern studies, os postcolonial studies especificamente com a história transnacional, que reflete sobre esses fenômenos de apropriação e reapropriação, é possível fazer a conexão entre todos. E quando os relacionamos, nos damos conta de que os povos dominados guardaram muitas coisas de suas dominações. E inversamente também. Os britânicos jogam polo, que originalmente não tem nada de britânico [risos], é absolutamente indiano. Enfim, e é isso que é interessante, ver por que Roma, que vence a Grécia, se heleniza no apogeu do Império. Isso é que é interessante, esses cruzamentos, essa mestiçagem, como diria Serge Gruzinski.

Temos, enfim, discussões extremamente férteis e enriquecedoras, o que faz com que, desse ponto de vista, sejamos ao mesmo tempo uma revista de história global, transnacional e de relações internacionais. Do ponto de vista global, até o momento, somos a única revista em língua francesa que faz isso.

\section{Não seria importante para a revista dar mais um passo? Considerar outros olhares? Quando observamos os membros do Comitê de Redação, vemos que são acadêmicos baseados na França. Até no Comitê Científico, onde há estrangeiros na equipe de redação, trata-se de historiadores atuantes em instituições do eixo Atlântico Norte...}

É verdade. Mas estamos de portas abertas! Infelizmente, em geral, esse tipo de iniciativa é feito por redes informais, de amizade, mas, de fato, seria importante abrii, estamos totalmente de acordo. Vemos aí a dificuldade típica desse tipo de iniciativa intelectual. Podemos 
ter boas ideias, mas quando as colocamos em prática, reencontramos os mesmos tropismos, os pesos, os hábitos... Podemos ter boas ideias, mas temos dificuldade de aplicá-las por falta de meios ou de imaginação.

\section{Esse comentário é interessante, porque o senhor esteve à frente do Comité International des Sciences Historiques (CISH). Não foi ele uma boa plataforma para se ter uma visão mais completa do mundo acadêmico? É verdade que essa rede é muito menos conhecida no Brasil que o IHTP...}

Sim, é uma pena e não deveria. Ela foi criada em 1926, tendo sido precedida por dois congressos mundiais. No CISH temos, de um lado, os comitês nacionais e, de outro, as organizações temáticas internacionais. 0 Brasil é um membro influente. Então é estranho o que você diz, que o CISH não seja conhecido no Brasil quando, na realidade, o Brasil é um membro influente. Dá medo [risos], porque quer dizer que há outros membros menos influentes onde o CISH deve ser ainda menos conhecido.

Na verdade, se o CISH não é conhecido, é bastante compreensível, porque uma das suas fraquezas, digamo-lo, é que em muitos países muitos dos grandes historiadores estão ocupados com suas obras ou têm uma relação muito distante com o comitê, o que é uma pena. Por outro lado, não será o CISH precursor de novos métodos e revoluções epistemológicas. A rigor, não poderia sê-lo, porque ele é feito de encontros. A primeira função do CISH é, a cada cinco anos, organizar um congresso. É uma máquina extremamente pesada. Portanto, ele não tem como ser um lugar de criação. É um contrassenso crer que ele é um lugar de criação. Em contrapartida, ele pode ser um lugar ideal para a circulação de informações, para servir de trampolim para inovações epistemológicas, que certamente vêm de outros lugares. Um trampolim para debates, para que, precisamente, o que se faça fora do CISH encontre nele, que é um espaço global, um verdadeiro espaço de confrontação, ou de informação.

Desse ponto de vista, a meu ver, o Congresso de Jinan, que se realizou em agosto de 2015, foi importante. Em primeiro lugar, a título simbólico, foi a primeira vez que um congresso mundial de ciências históricas se realizou fora da esfera ocidental. Quando vemos toda a série de congressos desde 1926, ou mesmo desde 1898, já que houve congressos mundiais muito antes do CISH, a sede era a Europa, sempre a velha Europa... Foi somente após 1995 que se estabeleceu uma alternância entre a Europa e outros lugares. Montreal em 95, Oslo em 2000, voltamos à Europa, Sidney em 2005, voltamos à Europa em 2010... Mas veja que Sidney ainda está na esfera ocidental! E, pela primeira vez, em 2015, Jinan, China! Criou-se assim certo estímulo novo, pois um dos temas centrais foi a China em 
perspectiva global. Estávamos aí, portanto, realmente na história transnacional e internacional da China, ou seja, de como a China, através de diferentes épocas, se abriu para o mundo, como o mundo entrava na China e como, portanto, todas essas circulações podiam se dar entre a China e o mundo.

0 segundo grande tema foi a historicização das emoções. Sobre esse tema, há alguns anos, alguns teriam dito "mas que tipo de história é isso? 0 que quer dizer?". Acredito que não foi a CISH que inventou a história das emoções, mas ela permitiu aos que eram pioneiros nessa história se expressar. 0 terceiro grande tema foi o tema das revoluções: conexões e comparação, mas pela primeira vez fizemos um quarto tema maior - em geral havia apenas três temas grandes. Dissemos que era preciso um quarto tema que fosse sobre epistemologia, método ou fontes. Assim, falamos sobre a virada digital. Digital turn, em que ela modifica nossa visão histórica e nosso ofício.

Outro novo fenômeno foi que, pela primeira vez, demos um prêmio internacional de história. Às vezes, para fazer graça, dizemos que é um "Prêmio Nobel de história", porque não há essa categoria no Prêmio Nobel. Ele veio bem a calhar, porque o primeiro a receber esse prêmio foi Serge Gruzinski, que, justamente, é um pioneiro da história global e transnacional. Eu diria mesmo da verdadeira história transnacional. Quer dizer, não é alguém que a faz porque está na moda [risos]. É um pioneiro, porque muitos fazem uma geleia transnacional e global, tendo por trás dessa geleia só verniz. Ele é realmente autêntico. Desse ponto de vista, portanto, espero que o CISH seja realmente um lugar de reunião, uma caixa de ressonância das viradas epistemológicas e de um tipo de debate que, na verdade, já acontecia. Se voltarmos a 1928, claro, chegaremos à famosa intervenção de Marc Bloch sobre a necessidade de sair dos quadros nacionais e fazer uma história comparada.

\section{Para passar ao futuro e terminar: pela primeira vez em 41 anos a Associação de Historiadores dos Estados Unidos constatou que em 2016 o número de postos de trabalho anunciados foi menor que a metade do número de doutorados obtidos no ano anterior. Qual é o seu diagnóstico sobre a situação da História das Relações Internacionais para os jovens que querem seguir carreira?}

Sim, na França também estamos muito inquietos porque, de modo geral, para a ciência histórica, há de fato muitas teses. Do ponto de vista do conhecimento, do avanço da ciência histórica, é muito bom que haja todas essas teses. É evidente que se raciocinarmos somente em termos econômicos e com relação ao número de vagas de emprego, talvez possamos dizer que, sim, há muitas teses para poucas colocações. Claro, podemos nos consolar dizendo que 
os excelentes pesquisadores, autores de teses excelentes, têm dificuldades para encontrar cargos, mas, no fim das contas, encontram. Ainda que se passem anos.

Sobre a História das Relações Internacionais, o que me inquieta especialmente é que, com 0 advento da virada cultural, que, claro, foi fundamental, alguns historiadores que não trabalham com relações internacionais, assim como fizeram Lucien Febvre nos anos 30 e Braudel nos anos 50 com relação a Renouvin, estejam impregnados da ideia de que a História das Relações Internacionais - ou a História Militar, ou ainda História Política - é uma história caducada, uma maneira desusada de se fazer história, a ponto de preferirem, para essa ou aquela vaga, escolher alguém que faça História Cultural "pura", ou História Social "pura" etc. Claro, estamos falando de candidatos também excelentes, e não tenho nada a dizer sobre isso. Entretanto, essa má imagem das relações internacionais é negativa no momento de algumas escolhas, e isso é um problema. É preciso lutar contra isso. Tanto é preciso lutar contra isso - e é minha convicção, ainda que, claro, eu possa estar errado -, que a História Cultural, hoje, deveria tomar cuidado [risos]. Um dia ela também estará em perigo! E já antevejo as premissas, porque frequentemente - não sempre, felizmente - para alguns ela está se transformando em uma história que anda em círculos. Uma história que já não é criativa como era há 20 ou 30 anos, mas que, devido ao seu empenho em encontrar objetos novos, interessantes, se torna uma história unicamente descritiva, feita com belas palavras que são transformadas em conceitos, os quais, ao serem examinados rapidamente, nota-se que não são conceitos, mas apenas palavras. De fato, é o que ocorre em sabatinas, diante de comissões... Quando essas lindas e poéticas palavras são pronunciadas por um candidato, todos fazem "Ohhh...!", admirados, mas quando vamos ler, por trás delas não há grande coisa! Já alguém que talvez tenha conceitos muito mais, como dizer... sólidos, ou mesmo alguém que tenha em mente a História Cultural ou Social e que não deixe de falar de Ciência Políica, vai parecer caduco, sobretudo porque não pronunciou as palavras mágicas. Eu acredito que, a partir do momento em que ciência se torna mágica, ela corre sério risco... [risos].

Uma outra condição que, imagino, irá mudar muito nas próximas décadas, são as fontes. Até aqui, ao menos, as fontes privilegiadas dos historiadores das Relações Internacionais têm sido os documentos, além da história oral. Com a era digital, parece que teremos uma enorme transformação. Tomemos como exemplo a gestão Bill Clinton nos Estados Unidos dos anos 90. Produziram-se então 40 milhões de e-mails. Mais adiante, somente o Departamento de Estado, no período em que teve Hillary Clinton à sua frente, produziu dois bilhões de e-mails. Esses exemplos dão uma ideia do que temos diante de nós. A pergunta é: como os historiadores do futuro conseguirão gerir a informação? 
Pois é... trata-se de uma questão gigantesca. Ligados a ela, temos dois aspectos. Por que não digitalizar os acervos antigos? A rigor, com a digitalização de arquivos antigos - 0 que é gigantesco sob o ponto de vista orçamentário - haverá a vantagem da disponibilização instantânea para o mundo inteiro. Não haverá necessidade de vir a Paris ou de ir a Roma ou a Londres para pesquisar. Será possível pesquisar na internet. A outra coisa é 0 arquivamento de dados digitais de hoje, mas que já são produzidos desde os anos 90. Nos ministérios da Defesa e das Relações Exteriores [da França], por exemplo, existe todo um plano para levar essa questão em consideração e para disciplinar os diplomatas e os tomadores de decisão no âmbito militar para que abram seus arquivos eletrônicos e deem respostas... mas tudo isso é gigantesco!

Como você disse, é um trabalho vastíssimo, mas, é bem verdade, tememos pelo historiador do futuro. 0 que ele poderá fazer? Há, no entanto, uma consolação em tudo isso. Por exemplo, Kissinger, em seu livro Diplomacia, lamentava o trabalho do historiador do futuro. Dizia que muitas coisas estavam sendo ditas não por escrito, mas por telefone, e portanto não haveria mais vestígio delas! Agora, com a era digital, as pessoas se telefonam menos [risos] e enviam mais e-mails, nos fazendo voltar à escrita. Pelo menos há isso! Mas é claro que podemos ficar pessimistas com os milhares de e-mails, é preciso gerir isso. Por hora, é sobretudo um problema de arquivamento. Se conseguirmos arquivar tudo, o problema do historiador do futuro será de gestão. Como ele fará? [risos] Como gerir, como fazer a triagem, como se encontrar? Felizmente, a vantagem do digital é que existem funções de pesquisa. Quando você tem um papel, não há função de pesquisa, é preciso ler todo o documento. Com o digital é possível, no mínimo, pesquisar por palavras-chave. 0 inconveniente é que, como sabemos, sem pensar nas palavras certas, deixamos escapar muita coisa [risos].

0 que é interessante é que a fonte, seja ela qual for, escrita tradicional, oral ou digital, exigirá as mesmas qualidades, as mesmas competências e muitos dos mesmos métodos, a saber: cruzamento de fontes. Há muitos métodos tradicionais de historiadores que não se modificarão fundamentalmente, mas o trabalho em si vai mudar. Mesmo se os métodos não mudarem necessariamente em relação às fontes, o ofício, em si, mudará.

\section{Sabemos que está aposentado, mas o senhor é professor emérito da Sorbonne e ainda trabalha muito. Quais são seus projetos hoje? 0 que podemos esperar?}

Acabo de sair de dois projetos. Um de 2015, que é um enorme projeto em que trabalhei anos: uma obra coletiva com 40 e tantos autores, em que fui ajudado por uma colaboradora, Alya Aglan. Dirigimos a obra 1937-1947: la guerre-monde [Paris, Gallimard, 2015]. Nossa 
ideia foi trabalhar uma guerra-mundo, que foi realmente mundial e que, por isso, merece uma história global [risos]. E aqui existe, talvez, uma nova contradição, porque temos 44 autores, e a maioria, infelizmente, é francesa [risos]. Felizmente nossa honra está salva, pois temos também não franceses, mas essa é outra demonstração da dificuldade de aplicar, na prática, novas abordagens. Publicamos 2.500 páginas em dois volumes, em que buscamos romper um pouco a cronologia, sem eurocentrismo, sem considerar uma guerra de 1939 a 45. Situamos entre 1937 e 47. Por que 47? Porque os tratados de paz, não os da Alemanha, mas dos outros, foram assinados em 47, e 37 porque queríamos levar em conta a Ásia. Claro, a questão da Manchúria vem antes de 37, mas a ideia é que entre 1931 e 37, mesmo com a Manchúria, os conflitos estavam separados, e a partir de 37 estavam ligados.

0 outro projeto, que me deixou muito feliz e que é completamente diferente, foi o livro Nossas humanidades. Fui procurado pela Editora Helium, que em princípio faz livros para crianças, livros para os pais lerem para os filhos. A ideia é justamente contar um pouco da história global, não falar somente da França ou da Europa, mas de todas as humanidades, e de como as diferentes humanidades fazem uma só e mesma humanidade, através de desenhos [e pequenos textos]. Assim, produzi diversas introduções que ao todo somaram cerca de 60 mil caracteres. 0 escritor Da Silva, que fez as legendas, produziu cerca de 30 ou 40 mil caracteres, e ainda assim o livro tem 500 páginas, quer dizer, é essencialmente desenho. Ele sairá em novembro próximo.

Estou bastante atrasado com outro projeto, que comecei através de um artigo na primeira edição de Monde(s), sobre as emoções em relações internacionais. Falar de emoções... fazer uma reflexão histórica sobre as emoções em relações internacionais no século XIX e século XX. Então, como você vê, tem coisa no forno! [risos] 